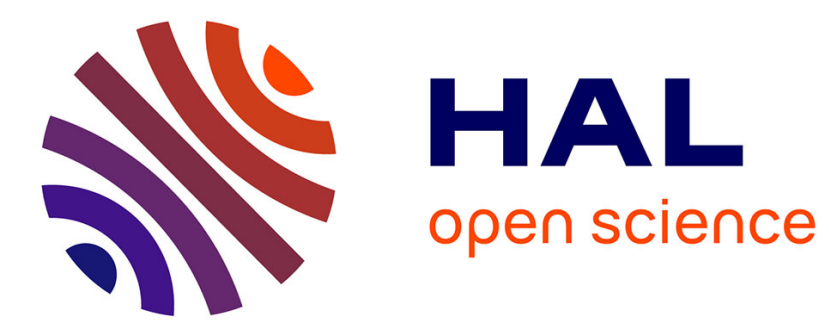

\title{
Soft power and corporate imperialism: maintaining British influence \\ Emma Bell
}

\section{To cite this version:}

Emma Bell. Soft power and corporate imperialism: maintaining British influence. Race and Class, 2016, 57 (4), pp.75 - 86. 10.1177/0306396815624865 . hal-01662053

\section{HAL Id: hal-01662053 \\ https://hal.univ-smb.fr/hal-01662053}

Submitted on 12 Dec 2017

HAL is a multi-disciplinary open access archive for the deposit and dissemination of scientific research documents, whether they are published or not. The documents may come from teaching and research institutions in France or abroad, or from public or private research centers.
L'archive ouverte pluridisciplinaire HAL, est destinée au dépôt et à la diffusion de documents scientifiques de niveau recherche, publiés ou non, émanant des établissements d'enseignement et de recherche français ou étrangers, des laboratoires publics ou privés. 


\section{Soft power and corporate imperialism: maintaining British influence}

\section{EMMA BELL}

Abstract: It is often suggested that Britain has lost its great power status since the fall of Empire. Yet, whilst its military and economic power has undoubtedly been weakened, it continues to exert power and influence and to promote national interests via the exercise of both hard and soft power. Far from representing a novel strategy, this simultaneous deployment of both forms of power may be considered as a continuation of the dual imperial strategy of gunboat diplomacy and winning hearts and minds at home and abroad. Yet, the postcolonial era does represent some novelty: as was clear under the Conservative-led coalition and is now evident under a Conservative majority government, soft power is no longer exercised principally via cultural diplomacy, through, for example, the British Council, but increasingly via large companies which promote British economic and political interests through corporate imperialism.

Keywords: corporate imperialism, international development, soft power, UK foreign policy

It is often thought that British imperialism died with the end of empire, the majority of contemporary studies focusing on US imperialism which has reportedly replaced that of the UK. ${ }^{1}$ It is said that the power and authority of the British state, notably its ability to influence and manipulate foreign nations and peoples in its own interests have been significantly weakened. Most recently, it has widely been asserted that Britain has been on the retreat from the world stage on account of reductions in defence spending to 2 per cent of GDP (the minimum NATO threshold), the former Conservative-Liberal Democrat coalition government's failure to secure support for military intervention in Syria in 2013, and its failure to take a leading role in European negotiations to resolve the crisis in Ukraine. Yet, this article asserts that British power and influence abroad is still significant, suggesting that

\footnotetext{
Emma Bell is senior lecturer in British Studies at the Universite de Savoie where she teaches courses on British history and politics, focusing particularly on neoliberal consensus politics. Her research on different aspects of state authoritarianism attempts to understand policy in its wider social and political context. She has published widely in France and the UK, notably Criminal Justice and Neoliberalism (Palgrave Macmillan, 2011) and Soft Power and Freedom under the Coalition (Palgrave Macmillan, 2015). She is the current coordinator of the European Group for the Study of Deviance and Social Control.
} 
British imperialism is alive and well. Far from being overshadowed by American imperialism, it has actually been reinforced by the Anglo-American 'special relationship'.

Although defence spending has been reduced, Britain remains an important military power: it is one of just nine states to possess nuclear arms and it retains 'a highly developed and experienced intelligence capability'. ${ }^{2}$ It is still capable of exercising 'hard power' and is currently deployed in over eighty countries around the globe. But it also exercises what Joseph Nye famously referred to as 'soft power'. ${ }^{3}$ Whilst hard power relies on military force to retain power and influence, soft power relies above all on the propagation of influence via cultural and political institutions which serve to render the country more attractive in the eyes of the world. There are moments in history when hard power prevails, such as when the dominant position of a country is threatened - an example is that of the United States which increasingly fell back on hard-power strategies following its loss of absolute economic dominance from the early 1990s onwards. ${ }^{4}$ Similarly, during the last days of empire, Britain often attempted to maintain its authority via the use of military force. Today, following the fall of empire, Britain only tends to exercise hard power with the support of the Americans.

The two forms of power are not mutually exclusive. Even in Iraq, military force was accompanied by propaganda campaigns aimed at winning the hearts and minds of the Iraqi people, as was often the case in Britain's colonial territories. For Nye, the deployment of both strategies is essential if one hopes to exercise power effectively - what he describes as 'smart power'. ${ }^{5}$ This article will demonstrate how one form of power effectively supports the other.

There is nothing new about the simultaneous use of hard and soft power. Yet the means via which power is exercised has changed considerably. It goes without saying that the methods of modern warfare are far removed from those of the past but this article focuses on new strategies of soft power. This continues to be exercised via cultural institutions such as the British Council but is now more likely to be promoted through large companies that are 
involved in what the British government refers to as 'commercial diplomacy'. As former Conservative foreign secretary William Hague put it, 'We have put commercial diplomacy at the heart of Britain's foreign policy, not only in order to secure our economic recovery and future prosperity but also to ensure our influence in the world is not diminished, promoting both our security and our ability to project our values. ${ }^{96}$ Soft power is thus not limited to a cultural imperialism that entails making British culture attractive to foreign nations: it now includes the promotion of corporate imperialism - imperialism promoted via British-based companies - which strengthens their economic power whilst simultaneously promoting the interests of the British state. Soft power thus allows British imperialism to spread in a new form.

In order to understand the role of corporations in contemporary British imperialism, it is first necessary to briefly highlight the symbiotic relationship that has always existed between the British state and private companies. Next, it is shown how hard power can serve to reinforce the soft power of companies and of the state itself. But corporations also contribute to the dissemination of soft power independently of the exercise of hard power, notably by providing consultancy services and becoming involved in humanitarian aid projects. Finally, I argue that it is above all soft power, as exercised via corporations, that serves to legitimise the power and authority of the British state today. The role of international development aid provided by the UK's Department for International Development (DfID) is crucial, ensuring much continuity between Conservative-led governments and their New Labour predecessors in the simultaneous pursuit of what are termed ethical as well as realist foreign policies.

\section{A symbiotic relationship between political and economic power}


There has always been considerable interdependence between economic and political power. Indeed, English commercial dominance in India predated military and political dominance over the territory, having been established by the East India Company when it was granted a commercial monopoly by the British Crown in 1600. It was the quest for economic dominance and the desire to eliminate competition from other colonial powers that led the Company to establish its own army and administrative department long before the British state took control of the region. ${ }^{7}$ In other words, it was in large part the existence of a commercial empire which facilitated the creation of a political empire.

Moreover, the British succeeded in establishing informal control over various territories outside the empire proper thanks to commercial links which helped to forge close relations between British and foreign business elites. One notable example is Argentina, ${ }^{8}$ which is often considered as part of the so-called 'informal' empire on account of the weight of commercial interests that Britain established in the country. ${ }^{9}$ Up until 1914, Argentina represented a source of investment for British companies and many banks were owned by the British. More generally, the country was 'at least during the years $1880-1914 \ldots$ more important than Egypt or China and, perhaps, even than India as a source of foodstuffs and raw materials, a market and a place for the investment of capital'. ${ }^{10}$ The local elites, los estancieros, adopted the gold standard in order to attract investment from London, which meant that they had to accept the rules of the City. ${ }^{11}$ Economic dependence thus entailed a degree of political dependence.

For economic historians Cain and Hopkins, the links between economic and political power were essential to the development of British colonial policy since the political and economic elites formed a unified class that shared a close correspondence of interests. They described them as 'gentleman capitalists', unified by the same world view. ${ }^{12}$ According to Cain and Hopkins, since at least 1688, 'the barriers between business and government were 
no more than mobile Chinese walls'. ${ }^{13}$ Their theory has been criticised, notably for having exaggerated the common mind-set of these elites. White, for example, argues that whilst elites from the City had privileged access to ministers, that did not necessarily mean that they managed to influence colonial policy in a significant way. ${ }^{14}$ In addition, he suggests that there was often a great divergence of opinions between the commercial elites in London and those in the colonies.

Cain and Hopkins' theory actually seems to be more relevant to the recent postcolonial era. The revolving door which allows ministers and other civil servants to move fluidly back and forth between the public and private sectors ${ }^{15}$ is without precedent, at least in the period since the second world war. Moreover, the lobbying industry gives large companies privileged access to Parliament, ${ }^{16}$ whilst government policies serve to promote the interests of the private sector. ${ }^{17}$ As I have explained in detail elsewhere, ${ }^{18}$ there is a genuine coalition of interests between the public and private sectors in Britain today. This may be said to closely resemble the class of 'gentlemen capitalists' described by Cain and Hopkins.

The power exercised by these elites might be considered as a form of soft power, even if it is often accompanied by hard power strategies. Nye's definition of soft power is generally limited to public diplomacy which seeks to influence the media and public opinion abroad and to forge closer relations with foreign countries through cultural and educational exchanges. ${ }^{19}$ Whilst these strategies have always played an important role in the promotion of national interests, companies have become ever more important as a means of extending British influence throughout the world.

This trend should be placed in the context of significant budget cuts which have affected the more traditional vehicles for the dissemination of soft power, notably the British Council and the BBC. The BBC World Service had its budget cut by 16 per cent over a fouryear period from 2010-2014 following the last government's spending review in 2010, 
leading to fears that its capacity to spread soft power throughout the world will be significantly diminished. ${ }^{20}$ The British Council was also negatively affected by the 2010 spending review, subject to a funding cut of 26 per cent over a five-year period up to $2015 .^{21}$ Added to this are the defence spending cuts highlighted above which may make the exercise of hard power somewhat more difficult. This hostile context, combined with the rapprochement between the private and the public sectors, helps us to understand why the British government is increasingly turning to corporations as the principal means of exercising soft power. Whilst spending has been cut elsewhere, the budget for overseas aid increased to reach the UN target of 0.7 per cent of gross national income in 2014 . The new Conservative-led government has recently passed the International Development Act which enshrines this minimum aid spending target in law. As will be demonstrated below, much of this spending has actually gone to private companies that are to contribute to the spread of British soft power abroad. This now seems to be the central prong of foreign policy. Yet, this does not mean that hard power has been abandoned. Indeed, hard power often facilitates the exercise of soft power, particularly in the form of corporate imperialism.

\section{Hard power in the service of soft power}

The occupation of Iraq serves as an example of the deployment of hard power in the service of soft power. Whilst the occupation might initially have appeared to be a failure of soft power to the extent that it damaged the reputation of Americans and their British allies, ${ }^{22}$ it nonetheless allowed them to establish important economic interests in the region and thus to spread their influence. Shortly after the invasion of Iraq in March 2003, the coalition government established by the Americans launched extensive reforms of the Iraqi economy in order to open it up to international markets. For the US Department of State, a planned economy represented yet another example of Sadaam Hussein's tyranny, creating an 
unfavourable business environment. ${ }^{23}$ Consequently, emergency legislation was passed, notably a law allowing the privatisation of public services and companies, opening them up to foreign investment. ${ }^{24}$ Numerous British (but more US) companies benefited from this law. DfID, the British Department of State responsible for providing humanitarian aid to Iraq, played a central role, granting contracts worth millions of pounds sterling to British companies. Many of these were consulting agencies, notably Adam Smith International, affiliated to the Adam Smith Institute, the influential think-tank whose reports largely helped to justify privatisation programmes in Britain at the end of the $1980 \mathrm{~s} .^{25}$ This agency advised the Iraqi government on the privatisation of public industries and utilities. ${ }^{26}$ Private military and security companies also benefited from contracts awarded by DfID, which provided them with $£ 278$ million of its total reconstruction budget. ${ }^{27}$ The extent of this subcontracting of security services to foreign companies is without precedent in British history.

The establishment of numerous British companies in Iraq allowed the British government to exercise soft power whilst projecting a positive national image which highlighted its role in the reconstruction and the securitisation of a country ravaged by years of famine and conflict. It represented an attempt to demonstrate that foreign policy was indeed guided primarily by ethical concerns, allowing the then New Labour government to inscribe its policy in Iraq as the continuity of its humanitarian interventions in Kosovo and Sierra Leone. Indeed, the companies benefiting from DfID contracts advertise their commitment to the positive values to which the United Kingdom professes to adhere. Adam Smith International, for example, proudly declares that it is working 'to fight against poverty and for economic growth for the citizens of countries facing the need for good governance, economic and social change'. ${ }^{28}$ The democratic reconstruction of such countries is thus seen to go hand in hand with the neoliberal reconstruction of its economy. 
Whilst the British experience in Iraq allowed the UK to follow its own post-imperial project, boosting the power of British capital abroad, ironically the country could not have benefited from the occupation had it not been part of the 'coalition of the willing' alongside the Americans. Yet, there are many fields in which the UK is not so dependent on its favoured allies, notably in the sale of arms and security expertise, areas in which it does not need to rely on the superior strength of American hard power.

\section{The defence and security industries as tools of soft power}

The main British company engaged in the sale of arms to foreign countries is BAE Systems which brings in profits totalling approximately 32 billion dollars per year. ${ }^{29}$ But the company is not only important for the British economy. Its sales play an important diplomatic role, allowing the UK to extend its soft power to the countries with which it does business. This viewpoint was clearly expressed by Nicholas Beadle, a researcher associated with the Royal United Services Institute, a think tank specialising in research on security and defence. In his witness statement to the parliamentary Select Committee on Soft Power and the Influence of the United Kingdom, he asserted that the sale of arms to countries which would otherwise be incapable of defending themselves is a particularly useful way to forge good long-term diplomatic relations and exercise political influence. Summing up this statement, the chair of the select committee declared, 'what is being done on the military side, including defence sales, is all part of supporting national interests more effectively than in the past, and it is very positive'.30

The consulting industry in transnational security also has significant value for the UK in the exercise of soft power. These companies, notably the British-based Control Risks, propose a large range of high-range security services and operate on a global scale. ${ }^{31}$ Control Risks does not only sell its consulting services but also seeks to influence the governments 
which buy its services. Although it claims to be independent, it works closely with the agency Security in Complex Environments, which seeks to influence the British government to 'contribute to the debate, shape policies and influence international fora'. ${ }^{32}$

For these companies to exert an effective influence on foreign governments, they need to be more than the purveyors of security and defence solutions but also to embody positive values and be seen to promote democracy and humanitarianism. As Nye suggests, soft power often involves the transmission of the desire to emulate the other. ${ }^{33}$

\section{Soft power and the legitimation of imperialism}

The British government and private companies share the same aim with regard to foreign policy: 'to promote British business interests, to work for open economies, to combat protectionism, and to work to remove barriers to business' ${ }^{34}$ Yet, these aims must be presented as being in the best interests of the countries concerned. Imperialist aims are thus dressed in the language of democracy and humanitarianism. The concern with self-interest represents a perpetuation of the realist tradition in British foreign policy as espoused by Lord Palmerston, then Conservative foreign secretary, in 1848, when he declared that Britain has 'no eternal allies, and we have no perpetual enemies. Our interests are eternal and perpetual, and those interests it is our duty to follow. ${ }^{35}$ Yet this realist approach, commonly associated with the Conservative Party, has been combined with a more ethical approach to foreign policy, most often identified with New Labour. In practice, New Labour never abandoned a realist approach, just as the Conservatives also identify with a broader ethical tradition. ${ }^{36}$ Indeed, it could be argued that this dual approach to foreign policy characterised the era of empire, just as it characterises the contemporary post-colonial era, even if there is more overt emphasis placed on the humanitarian/ethical dimension today. The Conservative Party has 
largely embraced the New Labour rhetorical emphasis on values whilst continuing to work towards the furtherance of British self-interest in foreign policy. ${ }^{37}$

Presenting economic protectionism as a barrier to democracy, as in the case of Iraq discussed above, is a good example of such a dual approach to foreign policy. The 'democratisation' of the country justified the imposition of anti-democratic neoliberal reforms which in practice took power away from local people by opening local markets up to exploitation by foreign capital. As Ayers has explained with reference to imperial strategies more generally, "self-determination does not mean autonomy. Rather it means the "freedom" to embrace the rules, norms and principles of the emerging (neo)liberal global order., ${ }^{38}$ Democratic ideals are thus used to promote neoliberalism and the interests of private capital which depend upon it.

The same might be said for humanitarian projects which are underpinned by neoliberal values promoting commercial interests whilst simultaneously spreading British soft power abroad. DfID plays a vital role here: in the words of Adam Smith International, it 'is arguably one of the most influential voices in the world of international development, second only, perhaps, to the World Bank and IMF' ${ }^{39}$ In terms of aid funding, it is the largest contributor of aid in real terms, after the United States, and ranks fifth overall if we take its contribution as a percentage of its gross national income. ${ }^{40}$ Much of this money is given directly to the Private Infrastructure Development Group (PIDG), a multilateral organisation founded in 2002 by DfID and three other international partners. It brings together different national aid agencies which provide its funding which it then uses to finance private companies which carry out infrastructure projects in poor countries. DfID is the single biggest contributor to the PIDG, contributing $\$ 662 \mathrm{~m}$ out of a total of almost $\$ 959 \mathrm{~m}$ of the total amount received for investment in private companies, affiliated programmes, project development and administration between 2002 and $2013 .^{41}$ It is notable that the level of investment has 
increased significantly in recent years, rising from an annual expenditure of over $\$ 23 \mathrm{~m}$ in 2010 to $\$ 233 \mathrm{~m}$ in $2013 .^{42}$ DfID aid funding also goes directly to private companies. One example is that of the British multinational Price Waterhouse Coopers which has been granted $£ 355$ million between 2011 and 2017 to manage the 'Girls’ Education Challenge', a project to encourage private investment in the provision of private education for girls in poor countries. ${ }^{43}$

Facilitating private sector investment in poor countries is now regarded as central to DfID's aid initiative. As its strategic framework made clear in 2014:

The private sector is the engine of growth. Successful businesses drive growth, create jobs and pay the taxes that finance services and investment. Foreign investment, and particularly exports, can accelerate domestic development. Governments have a role in encouraging responsible investment, and helping markets work better for poor people. ${ }^{44}$

Yet, as the Independent Commission for Aid Impact (ICAI), the body charged with scrutinising UK aid spending, highlights, there is limited evidence to demonstrate that donor support for private investment brings tangible benefits to the poor. ${ }^{45}$ It notes that it is unclear ‘whether DfID's contribution achieves impact beyond what would have been achieved anyway'. ${ }^{46}$ In the case of privatised education, many families will be unable to afford even the lowest of fees and private schools may only benefit children who would have previously been enrolled in public schools in any case. ${ }^{47}$ Furthermore, there is some evidence that DfID funding of private investment may do more harm than good. The National Audit Office (NAO) criticised DfID for lack of oversight over how the large sums of public money donated to the PIDG are spent. ${ }^{48}$ Consequently, there have been allegations that money has inadvertently encouraged the very kind of corruption that is said to be a hindrance to economic development in poor countries. In January 2015, for example, it was alleged that $£ 19$ m of money donated to PIDG had fallen into the hands of a convicted money launderer in Nigeria. $^{49}$ 
The British government's commitment to private sector investment as a means of combating poverty and promoting the development of poor countries suggests, in the absence of hard evidence concerning its efficiency, that policy is driven more by self-interest than by genuine humanitarian concerns. Yet, as noted above, one does not necessarily preclude the other, realist and value-based approaches to foreign policy having always been adopted simultaneously. The British government may possibly be motivated by humanitarian concerns but these appear to be ideologically driven and may conflict with 'realist' motives. Indeed, it would seem that the receipt of aid is conditional on recipient countries accepting neoliberal ideology and policies, notably economic restructuring to open markets up to investment for British companies. Neoliberal values are not only spread by government but have also permeated humanitarian aid agencies, whether they are independent of government or not. These agencies increasingly adopt a business culture characterised by a concern with presentation and the setting or clear and quantifiable targets. ${ }^{50}$ This leads to the promotion of a form of 'soft' neoliberalism whereby ideological objectives are dissimulated behind humanitarian rhetoric..$^{51}$

\section{Commercial diplomacy and great power status}

Using humanitarian aid to boost British business and investment abroad goes hand-in-hand with the government's broader aim of using commercial diplomacy as the primary means to enable Britain to achieve great power status. As William Hague recently noted, reflecting on his time as foreign secretary under the coalition government,

We've ... opened twenty new embassies and consulates and are closing very few. As a result, the link between economic and foreign policy has been restored, with a far more commercial emphasis on trade which I think if you believe, which is obviously true, that the economy is at the heart of everything else, should be the case ... I think our creation of new British chambers of commerce in about twenty countries is an excellent idea, more on the German model of how trade is promoted overseas. If those twenty are shown to be successful, that is the right sort of direction to go into for the long term ... 
Britain is expanding again, in terms of commercial effort, ministerial visits, members of embassies and consulates and we've done all that at this time of austerity. ${ }^{52}$

Discussion of foreign policy in the most recent Conservative manifesto was limited to how it can be used 'to boost our prosperity' by 'push[ing] for freer global trade, concluding major trade deals with the US, India and Japan and reinvigorating the World Trade Organisation' ${ }^{53}$ Rather than retreating from the world stage, it would seem that the Conservative government is simply seeking to secure power and influence by focusing on economic influence as a tool of soft power rather than on military influence. Yet its commitment to hard power has not been abandoned either. Under Prime Minister Cameron, the UK has been a willing partner in the military coalition to fight Islamic State and, at the time of writing, the new Home Secretary Michael Fallon, is discussing the possibility of seeking parliamentary support once again to launch air strikes against Syria. In this scenario, intervention may be justified on ethical grounds, just as military intervention in Afghanistan or Iraq was presented under New Labour, but it is also undoubtedly a means for Britain to project its power on the world stage. It has certainly not abandoned its old imperial pretensions, falling back on its economic and military power to maintain influence and authority throughout the globe.

However, Britain does not act alone but in partnership with old allies, notably the United States, which shares the goal of spreading neoliberal ideology throughout the globe. Consequently, US companies have also benefited from British foreign policy: one example is the consultancy firm GRM International which has received DfID funding to promote market solutions to healthcare problems in poor countries. ${ }^{54}$ Whilst America provides the military might, it would seem that the UK is becoming ever more adept at bringing its expertise in the spread of soft power to the Anglo-American relationship. This mutually beneficial partnership thus supports both British and American imperialism.

\section{Conclusion}


This discussion has identified a number of new inflections in British foreign policy, notably the Conservative Party's more overt commitment to an 'ethical' foreign policy focused on international development. Yet it has shown that the Party in government has also pursued a classic conservative realist approach, ensuring that such a policy works in its own best interests. There is much continuity with New Labour which had already experimented with corporate imperialism in Iraq whilst focusing on the ethical dimension of military intervention. However, there is also significant continuity with the imperialist project of the colonial era: foreign nations rendered economically dependent on Britain find themselves under her political influence, forced to accept fundamental ideological transformation; there is today a new class of 'gentleman capitalists', economic and political elites who share the same neoliberal vision of the world; hard power and soft power strategies are often combined to ensure the maximisation of national self-interest. Britain remains a significant player on the world stage yet, unlike in the past, she often needs to act in partnership with like-minded allies such as the United States. Nevertheless, whilst the latter may possess superior military might, it would seem that Britain's soft power credentials are more important. It is Britain that is currently doing most to support corporate imperialism, notably through significant spending on international development and the funding of organisations such as the PIDG, and it is Britain that comes out top on the international soft power ranking, just ahead of the US. ${ }^{55}$ British companies, particularly in the consulting and security sectors, are today the principal means of exporting soft power around the world. Engaging with humanitarian projects and the promotion of democracy, they are essential actors in a new project of British imperialism. It would thus seem that the 'informal' British empire is alive and well.

\section{References}

\footnotetext{
${ }^{1}$ D. Harvey, The New Imperialism (Oxford: Oxford University Press, 2003).

${ }^{2}$ J. Morris, 'How Great is Britain? Power, responsibility and Britain's future global role', British Journal of Politics and International Relations, vol. 13 (2011): p. 332.
} 
${ }^{3}$ J. S. Nye, Soft Power: the means to success in world politics (New York: Public Affairs, 2004).

${ }^{4}$ J. Go, 'Global fields and imperial forms: field theory and the British and American empires', Sociological Theory, vol. 26, no. 3 (2008): pp. 201-229.

${ }^{5}$ J. S. Nye, 'Public diplomacy and soft power', Annals of the American Academy of Political and Social Science, vol. 616, no. 1 (2008): p. 107.

${ }^{6} \mathrm{~W}$. Hague, speech to the Inward Investment Business Summit (11 July 2011),

https://www.gov.uk/government/speeches/foreign-secretary-commercial-diplomacy-at-the-heart-of-britainsforeign-policy.

${ }^{7}$ H.V. Bowen, The Business of Empire: the East India Company and imperial Britain, 1756-1833 (Cambridge: Cambridge University Press, 2008).

${ }^{8}$ A. Knight, 'Latin America', in J. Brown and R. Louis, The Oxford History of the British Empire: the twentieth century (Oxford: Oxford University Press, 2001 [1999]), p. 635.

${ }^{9}$ J. Darwin, The Empire Project: the rise and fall of the British world system 1830-1970 (Cambridge:

Cambridge University Press, 2009), p. 1; H. S. Ferns, 'Britain's informal empire in Argentina, 1806-1914', Past and Present, vol. 4, no. 1 (1953): pp. 60-75.

${ }^{10}$ Ferns, 'Britain's informal empire', p. 60.

${ }^{11}$ Darwin, The Empire Project, p. 279.

${ }^{12}$ P. Cain and T. Hopkins, British Imperialism: 1688-2000 (Harlow: Pearson, 2002 [1993]).

${ }^{13}$ Cain and Hopkins, British Imperialism, p. 43.

${ }^{14} \mathrm{~N}$. White, 'The business and politics of decolonisation: the British experience in the twentieth century', Economic History Review (vol. 53, 2000), pp. 544-64.

${ }^{15}$ Advisory Committee on Business Appointments, 'Appointments taken up by former ministers' (2014), http://acoba.independent.gov.uk/former_ministers/former_ministers_appointments_2012_.aspx.

${ }^{16}$ Commons Public Administration Select Committee, Lobbying: access and influence in Whitehall (London: The Stationery Office, 2009).

${ }^{17}$ ANON.

${ }^{18}$ ANON.

${ }^{19}$ Nye, 'Public diplomacy and soft power', pp.101-3.

${ }^{20} \mathrm{BBC}$, The Future of News (London: BBC, 2015).

${ }^{21}$ Foreign Affairs Committee, 'FCO performance and finances 2011-12' (2013), www.publications.parliament.uk/pa/cm201213/cmselect/cmfaff/690/69012.htm

${ }^{22}$ J. S. Nye, Unrevised transcript of evidence taken before The Select Committee on Soft Power and the UK's Influence, Tuesday 15 October 2013 (London: House of Lords, 2013), p. 17.

${ }^{23}$ D. Whyte, 'The crimes of neoliberal rule in occupied Iraq', British Journal of Criminology, vol. 47 (2007): p. 180.

${ }^{24}$ Whyte, 'The crimes of neoliberal rule', p. 181.

${ }^{25}$ Corporate Watch, Corporate Carve-up: the role of UK Corporations in Iraq, March 2003-March 2006, http://www.corporatewatch.org/download.php?id=41, pp. 9-10.

${ }^{26}$ Adam Smith International, 'Devising a strategy for state enterprise reform in Iraq' (2015),

http://www.adamsmithinternational.com/explore-our-work/middle-east-north-africa/iraq/state-enterprise-reformin-iraq/.

${ }^{27}$ Corporate Watch, Corporate Carve-up, p. 11.

${ }^{28}$ Adam Smith International, 'Devising a strategy for state enterprise reform in Iraq'.

${ }^{29}$ Stockholm International Peace Research Institute, ‘Armaments production: top 100’ (2014), http://www.sipri.org/ research/armaments/production/Top100. 
${ }^{30}$ House of Lords Select Committee on Soft Power and the UK's Influence, Oral and Written Evidence vol. 1(A-G), p. 198, http://www.parliament.uk/documents/lords-committees/soft-power-uk-influence/soft-power-evvol1-a-g.pdf.

${ }^{31}$ C. O’Reilly, 'L’évolution de l'offre des professionnels du risque mondialisé', Champ Pénal, vol. X (2013), http://champpenal.revues.org/8611?lang=en (page consulté le 19 janvier 2014).

${ }^{32}$ SCEG 'Security in Complex Environments Group (2014), https://www.adsgroup.org.uk/pages/24204653.asp

${ }^{33}$ Nye, 'Public diplomacy and soft power', p. 103.

${ }^{34}$ A. Mitchell, 'Oral evidence provided to the UK Parliamentary Committee on Soft Power and the UK's Influence', 10 June (London: House of Lords, 2013), p. 10.

${ }^{35}$ Cited in J. Gaskarth, 'Interpreting ethical foreign policy: traditions and dilemmas for policymakers', British Journal of Politics and International Relations, vol. 15 (2013): p. 195.

${ }^{36}$ Gaskarth, 'Interpreting ethical foreign policy'.

${ }^{37}$ M. Beech and T. J. Oliver, 'Humanitarian intervention and foreign policy in the Conservative-led coalition', Parliamentary Affairs, vol. 67 (2014): pp. 102-118.

${ }^{38}$ A. Ayers, 'Imperial liberties: democratisation and governance in the "new" imperial order', Political Studies, vol. 57 (2009): p. 1.

${ }^{39}$ Adam Smith International, 'Devising a strategy for state enterprise reform in Iraq'.

${ }^{40} \mathrm{OECD}$, 'Aid to developing countries rebounds in 2013 to reach an all-time high' (2013),

http://www.oecd.org/newsroom/aid-to-developing-countries-rebounds-in-2013-to-reach-an-all-time-high.htm

${ }^{41}$ PIDG, PIDG Annual Report 2013 (2014), http://www.pidg.org/resource-library/key-documents/annualreports/pidg-annual-report-2013.pdf/at_download/file, p. 107.

${ }^{42}$ PIDG Annual Report, p. 107.

${ }^{43}$ M. Curtis, Profiting from Poverty, Again: DfID's support for privatising education and health (London: Global Justice Now, 2015), p. 8.

${ }^{44}$ DfID, Economic development for shared prosperity and poverty reduction: a strategic framework (London: DfID, 2014).

${ }^{45}$ ICAI, Business in Development (2015), http://icai.independent.gov.uk/reports/business-in-development/, p. 23.

${ }^{46}$ ICAI, Business in Development, p. 26.

${ }^{47}$ Curtis, Profiting from Poverty.

${ }^{48}$ NAO, Oversight of the Private Infrastructure Development Group, HC 265 Session 2014-15, 4 July (London: NAO, 2014).

${ }^{49}$ R. Syal and S. Jones, 'Hundreds of millions given to foreign aid fund that lacked scrutiny, say MPs', The Guardian, 29 January, 2015, http://www.theguardian.com/politics/2015/jan/29/hundreds-of-millions-to-foreignaid-fund-lacked-scrutiny.

${ }^{50}$ M. Barnett, 'Humanitarianism transformed', Perspectives on Politics, vol. 3, no. 4 (2005): p. 733.

${ }^{51}$ J. Roberts, 'The state, empire and imperialism', Current Sociology, vol. 58, no. 6 (2010): p. 842.

${ }^{52}$ W. Hague, 'An interview with William Hague', The Economist, 11 April, 2015, http://www.economist.com/news/britain/21648248-britains-former-foreign-secretary-reflects-his-careerconservative-party-and-britains-foreign

${ }^{53}$ Conservative Party, The Conservative Party Manifesto 2015: strong leadership, a clear economic plan, a brighter, more secure future (London: Conservative Party, 2015), p. 76.

${ }^{54}$ Curtis, Profiting from Poverty, p. 13.

55 J. McClory, The New Persuaders III: an international ranking of soft power (London: Institute for Government, 2010), p. 11. 